\title{
Revegetation of tailings sand without a soil cover in the Alberta oil sands
}

\author{
J. Woosaree Land and Water Management, Alberta Innovates - Technology Futures, Canada
}

H.B. Anderson Reclamation and Closure Planning, Suncor Energy Inc., Canada

\begin{abstract}
Reclamation in the oil sands in Alberta is a high priority and can be challenging. Suncor Energy is in the process of reclaiming one of its consolidated tailings (CT) ponds (Pond 5). The CT is being capped with a layer of petroleum coke to accelerate the creation of a trafficable surface, and then with tailings sand. As these CT dewater, a temporary reclamation vegetative cover over the tailings sand was needed to stabilise the sand against water and wind erosion prior to final reclamation. Criteria for native plant species selection for the cover crop were based on their ability to grow rapidly, be drought and possibly salt tolerant and provide a vegetation cover for at least three years. This study aims to assess the potential of some native grasses to directly grow and stabilise tailings sand and to determine nutritional requirements for optimal growth.
\end{abstract}

The study was initiated in 2010 (Woosaree et al., 2010). Year 2011 provided an opportunity to study how well these native species continued to adapt and grow on direct tailings sands and if the underlying coke layer from the tailings ponds, presented any limitation to plant growth and survival.

Results indicated higher aboveground biomass and percent cover for the native grass seed mix than June grass or fringed brome grass alone. The higher biomass is most likely due to the nature of the species, with June grass being a low stature species compared to the native mix. Fringed brome plants were sparse within the plots, most likely as a result of low emergence in 2010. The greatest benefit of an organic amendment such as alfalfa pellet application appeared to be moisture retention, giving the seeded species a head start to germinate. Root depths measured ranged from 11 to $26 \mathrm{~cm}$ allowing the plants to tap deeper into below ground moisture. Plants in the control plots had less vigour, yet were still surviving despite no fertilisers or pellets being applied. A fertiliser rate above $50 \mathrm{~kg} \mathrm{~N} / \mathrm{ha}$ did not have a positive effect on the plants.

Soil available nitrogen measured in the fall of 2011 was below detectable level. However, plant tissue analysis showed total nitrogen of 1-2.3\%. Atmospheric deposition of $N$ and microbial association with the plant roots could contribute to $N$ availability. Microbial analysis revealed six nitrogen fixing bacteria and one plant growth-promoting bacteria to be associated with the native species roots. This study will help to select suitable species for inclusion in seed mixtures for final reclamation.

\section{$1 \quad$ Introduction}

In recent years, the oil sands industry has been a contentious issue in Alberta (Chapman and Das, 2010; Paskey and Steward, 2012). Reclamation is one of the attributes that drives the issues surrounding oil sands development and communicating the revegetation success associated with oil sands reclamation can lead to better understanding. Suncor Energy is in the process of reclaiming one of its consolidated tailings ponds (Pond 5). In order to deal with residual soft tailings still contained within the pond area, a capping and dewatering system is being used (Salifu et al., 2011). Petroleum coke is used to create the primary, floating trafficable cap, with vertical strip drains then installed to dewater and strengthen the underlying tailings. As these tailings dewater, additional loading is required to ensure dewatering of the top of the tailings column under the cap. This loading is to be accomplished through the placement of a layer of tailings sand on top of the coke, followed with a temporary reclamation cover over tailings sand to stabilise the sand against water and wind erosion prior to the final reclamation cover being established. A peat/mineral amendment 
is generally used to mitigate poor water retention in the sand, but rather than using stockpiled cover soil in the establishment of the temporary cover, an alternative amendment was desired.

Barley (Hordeum vulgare), is an annual species that has been the cover crop of choice for years. In 2010, Suncor Energy initiated a program to identify appropriate grass species, and to evaluate the use of alfalfa pellets (Medicago sativa) as an amendment to enhance plant establishment. Selection criteria for the grass species were based on the ability to provide rapid growth and a quick cover on the tailings and persistence for at least three years. An ability to improve soils via $\mathrm{N}$ fixation or rapid soil organic matter turn over, as well as drought, cold and salt tolerance would be desirable.

It was proposed that alfalfa pellets may improve soil structure and moisture retention and also serve as a slow release fertiliser providing nutrition to plants.

In 2010, enhanced plant emergence and growth were observed. First year's results suggested that alfalfa pellets at 5 tons/ha and fertiliser at $50 \mathrm{~kg} \mathrm{~N} / \mathrm{ha}$ can improve soil structure and enhance vegetation growth (Woosaree and Hiltz, 2010). There were indications that not all the alfalfa pellets were mineralised and could serve as a slow release fertiliser in the following year, reducing the need for further fertiliser applications. In 2010, only the barley and oat (Avena sativa) plants matured. The native grasses, fringed brome grass (Bromus ciliatus) and June grass (Koeleria macrantha), as well as a mixture of native grasses containing Slender wheatgrass (Elymus trachycaulus), Rocky Mountain fescue (Festuca saximontana), Spike trisetum (Trisetum spicatum), June grass, fringed brome, Canada wild rye (Elymus canadensis), and Tufted hair grass (Deschampsia caespitosa) were at the seedling stage by the end of the growing season. Compared to barley and oats, native species took a longer time (2-3 years) to establish and the 2011 growing season provided additional information on their adaptation to growing on tailing sands. Providing more nutrients to the plants, in terms of fertiliser input does not necessarily lead to more nutrient uptake. A considerable amount of $\mathrm{N}$ fertiliser was unaccounted for in 2010 and 2011, most likely lost through soil leaching and volatilisation. Nitrogen use efficiency measured for barley and oats in 2010 ranged from $2-17 \%$.

This study aims to: assess the potential of native grasses to directly grow and stabilise tailings sand and determine nutritional requirements for optimal growth.

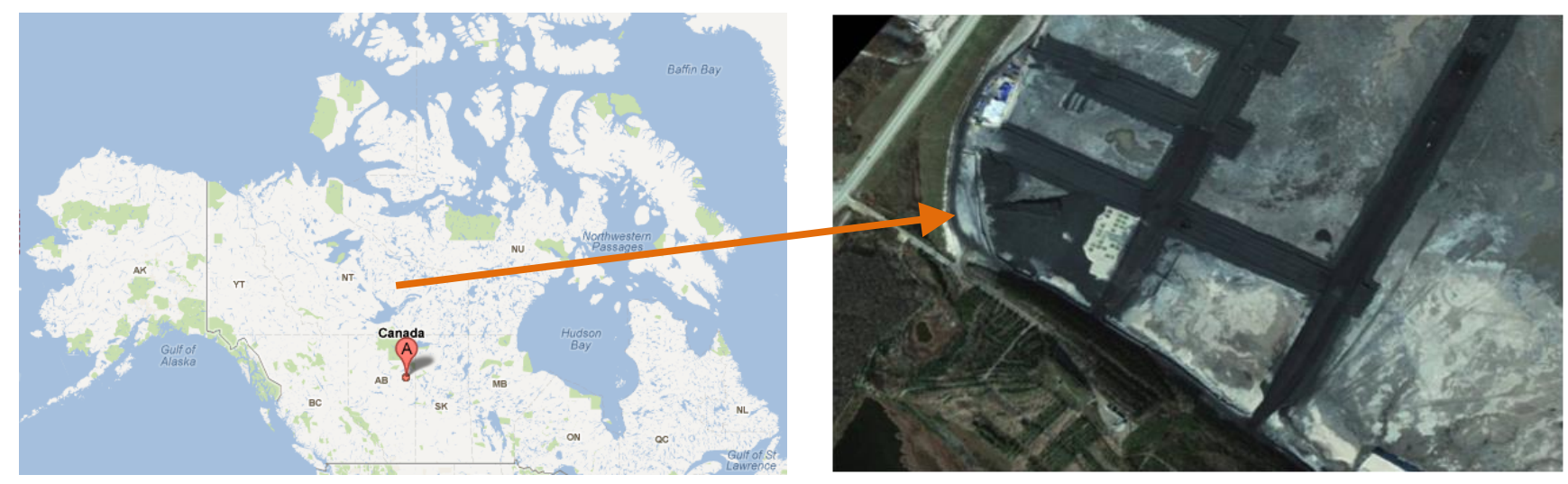

Figure 1 Location of study site, Northern Alberta, Canada (Google Earth)

\section{$2 \quad$ Methodology}

In 2010, the study was established on a 1 ha tailings sand pad that was constructed on Pond 5 at the Suncor Energy site. The study consisted of:

- Three replicate blocks, with each block being $100 \times 20$ m. A 2 m buffer strip separates each block. Species were randomly assigned within each block.

- Each block was split into three whole plots for alfalfa pellet application at 5, 10 and 20 t/ha. 
- Each whole plot was split into five subplots, containing different cover crops (barley, oats, June grass, fringe brome grass and a mixture of native grasses).

- Each subplot was split into two split plots, with different fertiliser rates -50 and $250 \mathrm{~kg} \mathrm{~N} / \mathrm{ha}$.

- Data collected in 2011 included: percent of plot covered by plants, available nitrogen in soils, total nitrogen in the plants (root and shoots), plant health, including any beneficial microbial association with the native species, plant height, plant root depth and plant biomass. Root depths were measured (1-3 replicates) by carefully digging close to the plants. We also looked for any signs of root obstruction such as necrosis, die back of part of the roots or alteration of normal appearance of the roots.

\subsection{Soil moisture content determination}

Soil water content within the top $30 \mathrm{~cm}$ layer was measured at time of seeding. Three measurements were recorded from random locations within each experimental unit using a hand held TDR probe (Moisture Point, Victoria, BC).

Precipitation, mainly rainfall data was obtained from a Suncor Energy local weather station. This weather data was compared to climate norms for temperatures and precipitation at Fort McMurray.

\subsection{Available $\mathrm{NH}_{4}{ }^{+}-\mathrm{N}$ and $\mathrm{NO}_{3}{ }^{-}-\mathrm{N}$ determination}

\subsubsection{Soils analysis}

Soil samples were taken from each sub-plot and the replicates were combined and brought to AITF laboratory for processing. Sample preparation and analysis followed the methods described by Maynard et al. (2008). Inorganic nitrogen is mostly found as $\mathrm{NH}_{4}{ }^{+}$and $\mathrm{NO}_{3}{ }^{-}$in soils. The most common extractant for $\mathrm{NH}_{4}{ }^{+}$and $\mathrm{NO}_{3}{ }^{-}$is a solution of $2.0 \mathrm{M} \mathrm{KCl}$.

Only exchangeable $\mathrm{NH}_{4}{ }^{+}$can be determined using this procedure, although it is important to note that fixed $\mathrm{NH}_{4}{ }^{+}$does contribute significantly to nitrogen in soil samples. Fixed ammonium is defined as the portion of $\mathrm{NH}_{4}{ }^{+}$that cannot be exchanged by a neutral potassium salt solution. Nitrate is soluble in water and can be extracted using $\mathrm{KCl}$.

Available $\mathrm{N}$ analysis should be performed on moist soils shortly after collection. However, if this was not possible, then soil samples that were air-dried at low temperatures (room temperature) in an $\mathrm{NH}_{4}{ }^{+}$-free environment can be used.

For tissue analysis, whole plant samples (10 plants with roots) were collected from each sub-plot and were transported to AITF laboratory, washed, oven dried at $70^{\circ} \mathrm{C}$ and ground in a coffee grinder. Total nitrogen was determined using a LECO Truspec CNS analyser, with the furnace running at $950^{\circ} \mathrm{C}$ and calibrated using EDTA (LECO std), Apple Leaves (NIST std), Glycine (Fisher Chemicals), Nicotinic Acid (Fisher Chemicals) and Std A (an in-house alfalfa dust) run every 10 samples (Campbell and Plank, 1998).

For nitrogen and carbon analyses, the samples were combusted at $950^{\circ} \mathrm{C}$ and set through a secondary furnace at $850^{\circ} \mathrm{C}$. The combusted gases are collected and sent through a $\mathrm{CO}_{2}$ infrared detector where carbon is measured as $\mathrm{CO}_{2}$ (Horneck and Miller, 1998). The nitrogen is measured as $\mathrm{N}_{2}$ by a thermal conductivity cell. The results are displayed as weight \% or ppm.

\subsection{Microbial analysis}

Twenty-seven soil samples from near the plant roots were collected from the experimental site (9 treatments $\times 3$ replicates) during fall of 2011. The replicate samples were combined and mixed. 


\subsubsection{Total bacterial population}

A $10 \mathrm{~g}$ mixed wet sample of each treatment was suspended in $90 \mathrm{~mL}$ of $0.2 \%$ water agar $\left(10^{-1}\right)$ and shaken for $0.5 \mathrm{~h}$ on a shaker at $200 \mathrm{rpm}$. A sub-sample of this initial dilution was used to prepare a dilution series in $0.1 \%$ peptone solution $\left(10^{-2}-10^{-5}\right)$. A $100 \mu \mathrm{l}$ aliquot of each dilution was spread onto a Potato Dextrose Agar (PDA) plate (two plates/dilution) for total colony counts. Plates were incubated at room temperature for three days. The total bacterial colonies were counted 3 days after incubation. The moisture content of each sample was measured by collecting a $10 \mathrm{~g}$ wet sample and oven $\left(60^{\circ} \mathrm{C}\right)$ dried for two days, followed by reweighing the sample. Bacterial load (cfu/g dry soil material) of each treatment was then calculated.

\subsubsection{Bacterial identification}

Twenty-two representative single bacterial colonies were transferred to Tryptic Soy Agar (TSA) plates and cultured at room temperature for seven days. Then they were identified using Gram staining, as well as DNA sequence analysis.

Gram staining: Twenty-two bacteria colonies were transferred from TSA plate to Tryptic Soy Broth (TSB) and cultured at $26^{\circ} \mathrm{C}, 200 \mathrm{rpm}$ for two days. Then the bacteria were stained following the Gram staining procedure, examined under a compound microscope (Zeiss, Germany) and microphotographs were taken at 1,000 x magnification using a digital camera device (Spot Imaging Solutions, Diagnostic Instruments Inc. $\mathrm{MI}, \mathrm{USA})$.

DNA sequencing: Genomic DNA was extracted and processed by PCR using 16s rDNA primers (Prokaryote $16 S$ F 5'-AGAGTTTGATCCTGGCTCAG/16S R 5'-GGTTACCTTGTTACGACTT). The DNA fragments from PCR products were purified using a gel extraction kit, sequenced and compared to relevant sequences in the NCBI BLASTN database and Ribosomal Database Project 10 (http://rdp.cme.msu.edu/index.jsp, Aug 2011).

\subsection{Data analysis}

A split-split randomised plot design (Figure 1) with three replicates was used to compare different species (June grass, Fringe brome and a native mix consisted of Slender wheatgrass (Elymus trachycaulus), Rocky Mountain fescue (Festuca saximontana), Spike trisetum (Trisetum spicatum), June grass (Koeleria macrantha), fringed brome, Canada wild rye (Elymus Canadensis) and tufted hair grass (Deschampsia caespitosa), fertiliser rates (50 and $250 \mathrm{~kg} \mathrm{~N} / \mathrm{ha}$ ) and the application of alfalfa pellets (5, 10, and $20 \mathrm{t} / \mathrm{ha}$ ) in terms of growth success.

Nitrogen concentrations in soil and in tissue were also determined, however, this data was not statistically evaluated as the soil samples from the three replicates were combined. Plant heights were compared between fertiliser rates and pellets for each mix separately. Percent cover and aboveground biomass were compared across seed mixes. The statistical analyses were performed using SAS Release 9.3 (64-bit) for Windows 7 (SAS Institute Inc., 2010). SAS MIXED procedure was used to analyse the data. If the model revealed statistical significance $(p \leq 0.05)$, Tukey-Kramer adjusted comparisons were used to determine if pair-wise differences existed between the levels. Percent cover and aboveground biomass were normalised using square-root and log-transformations of the value+1, respectively.

\section{$3 \quad$ Results}

\subsection{Plant growth}

Precipitation during the growing season (May to September) in 2011 was $144.8 \mathrm{~mm}$, which is $88.1 \mathrm{~mm}$ less rainfall than the 19-year average for that period $(225.9 \mathrm{~mm})$. The early season was generally dry and there was hardly any precipitation until June 14th, 2011 when the plants received $2.8 \mathrm{~mm}$ of rain. Despite the lack of moisture in the early part of the growing season, the native plants grew to full maturity. The seeded native grasses in the control plot (no alfalfa pellets and no fertiliser application in 2010) recovered from the 2010 winter period but appeared to be suffering from drought stress compared to areas that received alfalfa pellet amendments. Soil moisture in the later part of the growing season (June 15th and onward, 
$52.8 \mathrm{~mm}$; July $-23.9 \mathrm{~mm}$, August $-26.2 \mathrm{~mm}$ and September $26.9 \mathrm{~mm}$ ) enabled the plants to grow and survived the saltation process (blown in sand) at Pond 5 . Seeded native grasses from the no fertiliser and no alfalfa pellets amendments appeared to have delayed establishment and development (Figure 2) compared to the alfalfa amended plots. Near the growing season's end, the plants were thriving and able to withstand burial and trampling by sand (Figure 2).
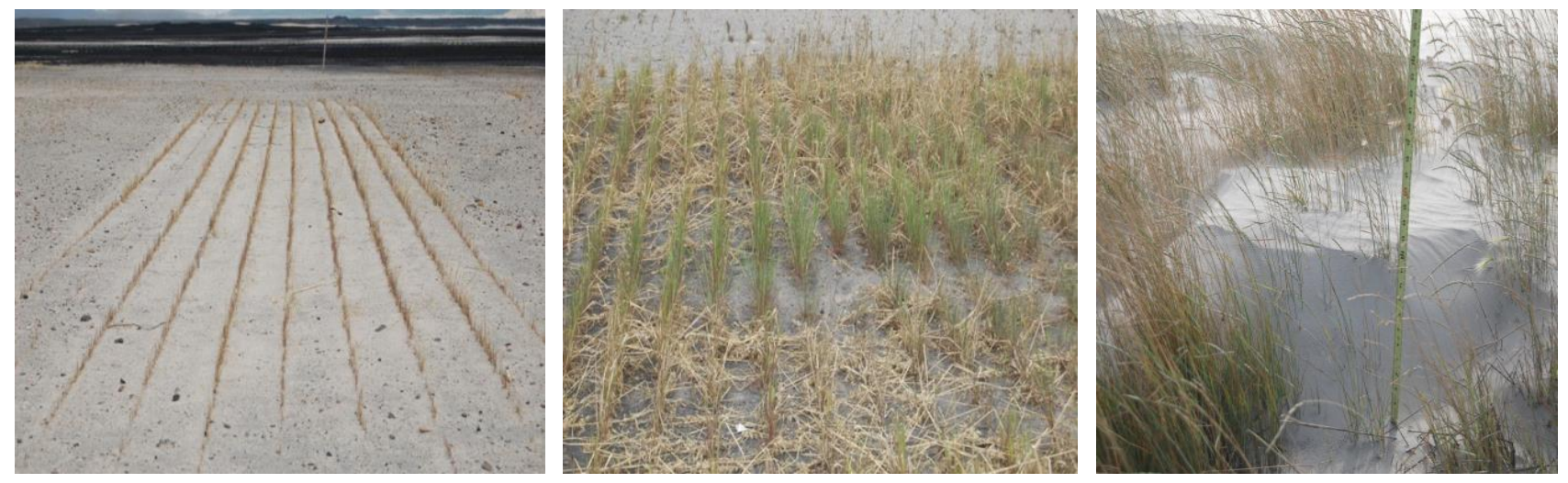

Figure 2 Native grass growth in non-amended (L) compared to alfalfa pellets amended plots (C) in early spring of 2011 and in the summer season (R)

Overall there was a significantly higher aboveground biomass for areas fertilised with $50 \mathrm{~kg} \mathrm{~N} / \mathrm{ha}$ than for areas fertilised with $250 \mathrm{~kg} \mathrm{~N} / \mathrm{ha}$ (Table $1 ; \mathrm{p}=0.0457$ ). There was also a significant effect of species aboveground biomass $(p<0.0001)$, with the native seed mix having significantly higher aboveground biomass than fringed brome $(p<0.0001)$ and June grass $(p=0.0002)$. June grass had significantly higher aboveground biomass than fringed brome $(p=0.0018)$.

Native seed mix with $5 \mathrm{t} / \mathrm{ha}$ of alfalfa pellet application had significantly higher aboveground biomass than fringed brome with $5 \mathrm{t} / \mathrm{ha}$ alfalfa pellet application $(p=0.0009)$. In addition, June grass and native seed mix with $10 \mathrm{t} /$ ha of pellet application had significantly higher aboveground biomass than fringed brome with $10 \mathrm{t} / \mathrm{ha}$ alfalfa pellet application ( $p=0.0018$ and $p<0.0001$, respectively).

Plant cover (Table 1) showed significant difference between mixes in $2011(p<0.0001)$. June grass and native mix had significantly higher percent cover than fringed brome (both $\mathrm{p}<0.0001$ ) and native mix had significantly higher percent cover than June grass $(p<0.0001)$.

There were no significant differences in plant heights between alfalfa pellet application levels or fertiliser rates for any of the mixes (all $p>0.15$ ).

\subsection{Effect of alfalfa pellets rate and coke depth placement on root development}

No marked differences were observed for root growth and development as a result of different alfalfa pellet applications in 2010 (Figure 3). June grass, Fringe brome grass and the Native seed mix growing in plots having $20 \mathrm{t} / \mathrm{ha}$ of alfalfa pellets had slightly deeper roots compared to plots having $5 \mathrm{t} / \mathrm{ha}$ alfalfa pellets (17 versus $22 \mathrm{~cm}, 18$ versus $20 \mathrm{~cm}$ and 20 versus $23 \mathrm{~cm}$ ).

All species grew well (Figures 4 ) and were not constrained by depth of tailings sand placement prior to the roots reaching the underground coke layer. In plots that had $5 \mathrm{t} /$ ha of alfalfa pellets, roots of June grass grew to $18-20 \mathrm{~cm}$ deep. This value did not differ much for areas that received more alfalfa pellets. At $10 \mathrm{t} /$ ha, June grass roots grew to $17-19 \mathrm{~cm}$ and to $16 \mathrm{~cm}$ under the $20 \mathrm{t} /$ ha pellet application. The trend is similar for Fringe brome grass $(11-20 \mathrm{~cm})$ and the native grass mix $(19-24 \mathrm{~cm})$ at different alfalfa pellet application and tailings sand placement. native species, with their deep fibrous roots grew approximately $4 \mathrm{~cm}$ by the first season and up to $20 \mathrm{~cm}$ by end of the growing season in 2011 . Plants in the control area had shallower roots, ranging from $9-15 \mathrm{~cm}$. 
Table 1 Summary statistics for aboveground biomass, plant cover and plant height, by species, alfalfa pellet application and fertiliser rate

\begin{tabular}{|c|c|c|c|c|c|c|}
\hline Mix & $\begin{array}{l}\text { Alfalfa } \\
\text { Pellets } \\
\text { (t/ha) }\end{array}$ & $\begin{array}{l}\text { Fertiliser } \\
\text { Rate } \\
\text { (kg N/ha) }\end{array}$ & $\mathbf{N}$ & $\begin{array}{c}\text { Mean (SD) for } \\
\text { Aboveground } \\
\text { Biomass (kg/ha) })^{1,2}\end{array}$ & $\begin{array}{l}\text { Mean (SD) for } \\
\text { Plant Cover }\end{array}$ & $\begin{array}{c}\text { Mean (SD) for } \\
\text { Plant Height }\end{array}$ \\
\hline \multirow{6}{*}{$\begin{array}{l}\text { Fringed } \\
\text { brome }\end{array}$} & 5 & 50 & 3 & $108.33(50.16)$ & $18.33(11.55)$ & $29.56(5.01)$ \\
\hline & & 250 & 3 & $34.00(32.60)$ & $11.67(5.77)$ & $27.92(2.95)$ \\
\hline & 10 & 50 & 3 & $153.67(200.15)$ & $16.67(7.64)$ & $31.19(6.30)$ \\
\hline & & 250 & 3 & $105.33(182.44)$ & $23.33(17.56)$ & $34.62(5.29)$ \\
\hline & 20 & 50 & 3 & $233.00(185.21)$ & $11.67(5.77)$ & $26.33(5.29)$ \\
\hline & & 250 & 3 & 302.67 (241.78) & $11.00(1.73)$ & $25.12(6.93)$ \\
\hline \multirow[t]{6}{*}{ June grass } & 5 & 50 & 3 & 368.67 (128.41) & $48.33(23.63)$ & $26.50(15.46)$ \\
\hline & & 250 & 3 & 80.33 (49.34) & $45.00(27.84)$ & $24.99(20.88)$ \\
\hline & 10 & 50 & 3 & $605.67(150.58)$ & $58.33(15.28)$ & $19.16(9.76)$ \\
\hline & & 250 & 3 & 397.67 (172.18) & $53.33(10.41)$ & $18.88(5.38)$ \\
\hline & 20 & 50 & 3 & $404.33(302.32)$ & $46.67(7.64)$ & $20.20(4.57)$ \\
\hline & & 250 & 3 & 203.00 (175.07) & $46.67(5.77)$ & $20.20(3.91)$ \\
\hline \multirow{6}{*}{$\begin{array}{l}\text { Native } \\
\text { grass mix }\end{array}$} & 5 & 50 & 3 & $1,671.00(837.76)$ & $94.00(7.94)$ & $51.42(4.77)$ \\
\hline & & 250 & 3 & $1,467.33(736.10)$ & $85.67(6.03)$ & $51.76(2.82)$ \\
\hline & 10 & 50 & 3 & $3,222.00(620.89)$ & $83.33(2.89)$ & $52.64(10.22)$ \\
\hline & & 250 & 3 & $1,629.00(654.34)$ & $78.33(5.77)$ & $55.81(8.60)$ \\
\hline & 20 & 50 & 3 & $2,327.33(2,272.56)$ & $95.00(5.00)$ & $56.19(7.82)$ \\
\hline & & 250 & 3 & $2,440.00(1,463.24)$ & $86.67(7.64)$ & $51.51(12.11)$ \\
\hline
\end{tabular}

Note: $>$ indicates significantly $(p \leq 0.05)$ greater than.

${ }^{1}$ Native mix $>$ June grass $>$ fringed brome.

$250 \mathrm{~kg} \mathrm{~N} / \mathrm{ha}>250 \mathrm{~kg} \mathrm{~N} / \mathrm{ha}$ of fertiliser.

\subsection{Nitrogen retention}

Figure 5 shows total percent nitrogen in plant tissues (root and shoots) at the end of the growing season of 2010 and 2011. No major differences were observed. Nitrogen uptake by all plant species during 2011 remains fairly consistent following a similar trend to 2010. Uptake of nitrogen by fringed brome grass increased with nitrogen availability in 2010 from $3.6 \%$ to approximately $5 \%$ as alfalfa pellets increased. Similarly, with increased nitrogen to $250 \mathrm{~kg} \mathrm{~N} / \mathrm{ha}, \mathrm{N}$ uptake increased from 4.3 to $4.5 \%$.

The trend is similar for June grass and the native grass mix. In 2010, nitrogen uptake in June grass ranged from 3 to $3.75 \%$ and from 2.8 to $3.9 \%$ for the native grass mix. In 2011, nutrients became limited and nitrogen uptake varied from approximately 1 to $2.3 \%$. 


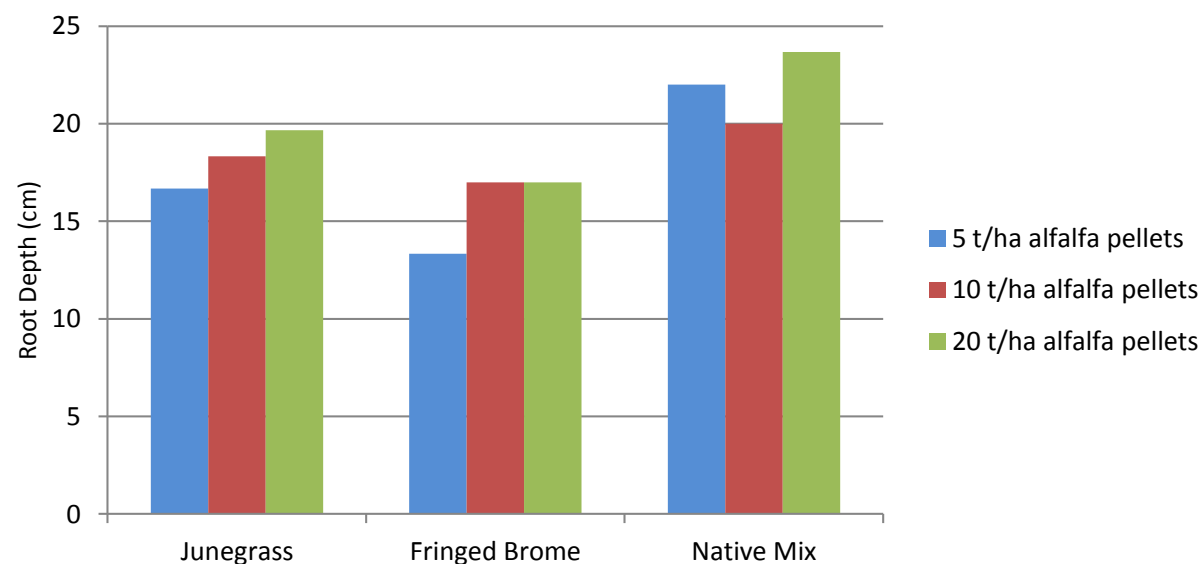

Figure 3 Average root length as affected by alfalfa pellets rate ( $t / h a)$ and tailings sand capping depth
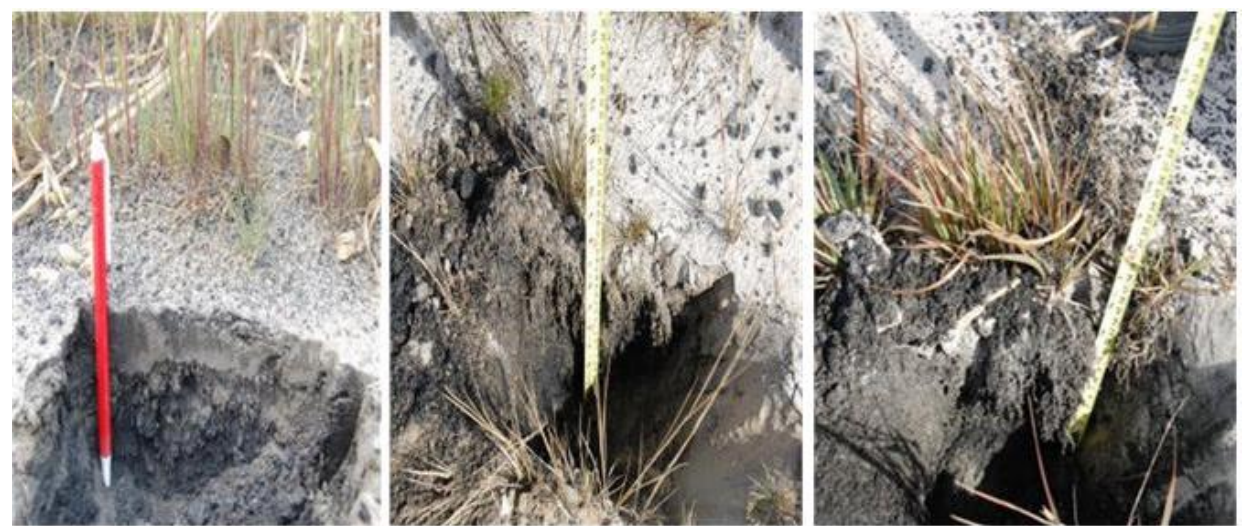

Figure 4 Growth of native grasses showing healthy roots not restricted by the coke layer in the shallow end $(0-30 \mathrm{~cm})$ of the tailings sand placement on the plots

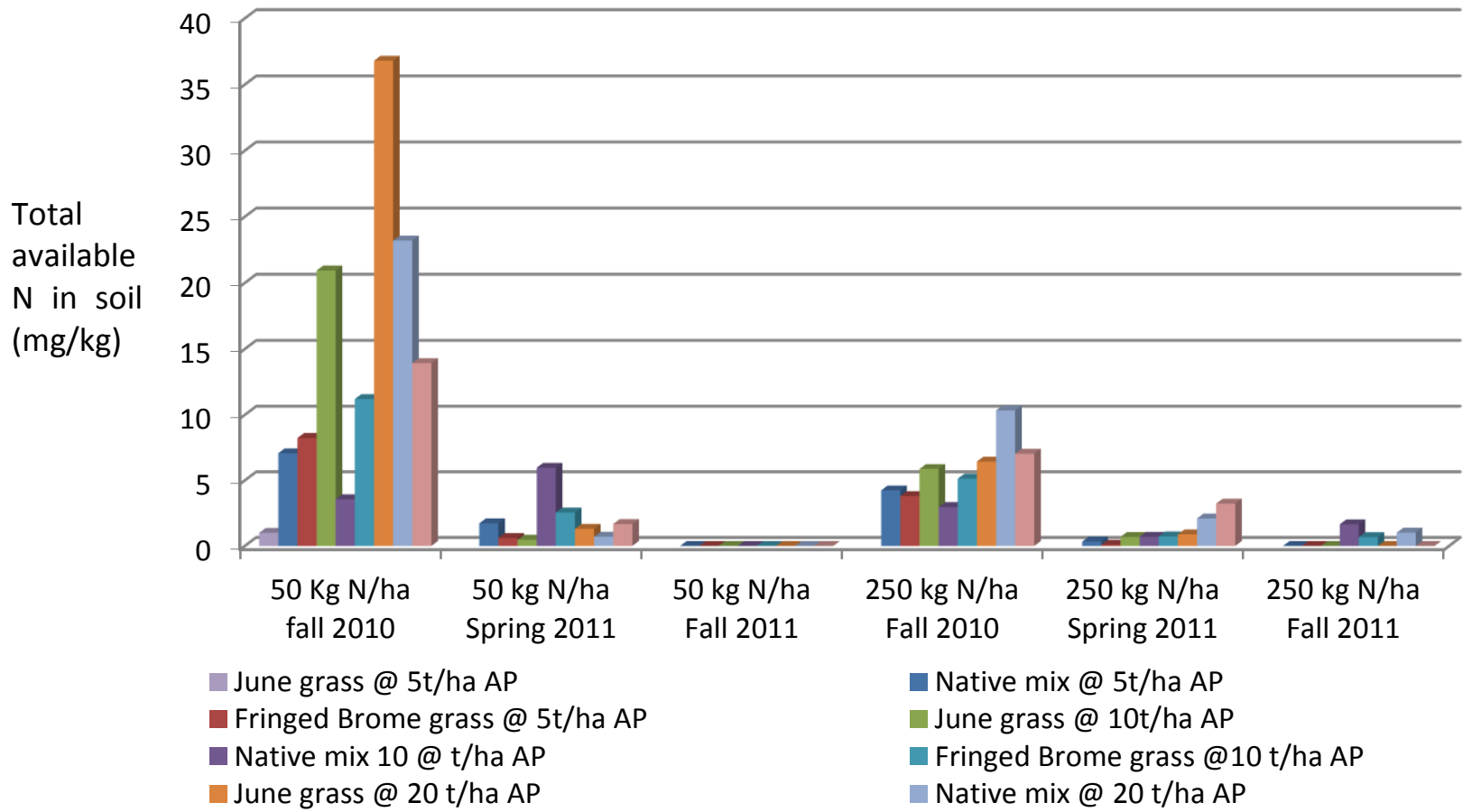

Figure 5 Soil available nitrogen as influenced by alfalfa pellet (AP) and fertiliser from 2010 application 


\subsection{Microbial association with native plantings}

Bacteria were the dominant microbes in the tailings sand soils. Bacterial loads in the soil samples ranged between $4.9 \times 10^{6}$ and $3.0 \times 10^{8} \mathrm{cfu}$ (colony forming unit) per gram dry soil (Table 2 ).

Table 2 Enumeration of bacteria from soil samples collected at $30 \mathrm{~cm}$ depth near the root zone

\begin{tabular}{lccc}
\hline Treatment & $\begin{array}{c}\text { Alfalfa Pellet } \\
\text { Rate (t/ha) }\end{array}$ & Seed Mix & $\begin{array}{c}\text { Bacterial Population } \\
\text { (colony forming units/g) }\end{array}$ \\
\hline 1 & 5 & Native grass mix & $1.6 \times 10^{7}$ \\
2 & 5 & Fringed brome & $4.9 \times 10^{6}$ \\
3 & 5 & June grass & $1.6 \times 10^{7}$ \\
4 & 10 & Native grass mix & $5.9 \times 10^{6}$ \\
5 & 10 & Fringed brome & $3.1 \times 10^{8}$ \\
6 & 10 & June grass & $5.9 \times 10^{6}$ \\
7 & 20 & Native mix & $8.0 \times 10^{6}$ \\
8 & 20 & Fringed brome & $6.3 \times 10^{6}$ \\
9 & 20 & June grass & $7.4 \times 10^{6}$ \\
\hline
\end{tabular}

Treatments seeded with Bromus ciliatus and $10 \mathrm{t} / \mathrm{ha}$ alfalfa pellet rate had the highest bacterial load. Some fungal colonies, including Botrytis sp., Cladosporium sp., Fusarium sp., Rhizopus sp., Trichoderma sp. and Penicillium sp., were found in the soil samples. Twenty-two representative bacterial colonies were differentiated by Gram staining. Nine Gram positive and 13 Gram negative were identified. The shape of bacterial cells ranged from coccus to filamentous but the majority was rod-shaped (Figure 6). DNA identification of 18 representative isolates showed that Bacillus spp. and Pseudomonas spp. were the major bacteria present. Other bacteria including Arthrobacter sp., Flavobacterium sp. and Xanthomonas sp. were also present.
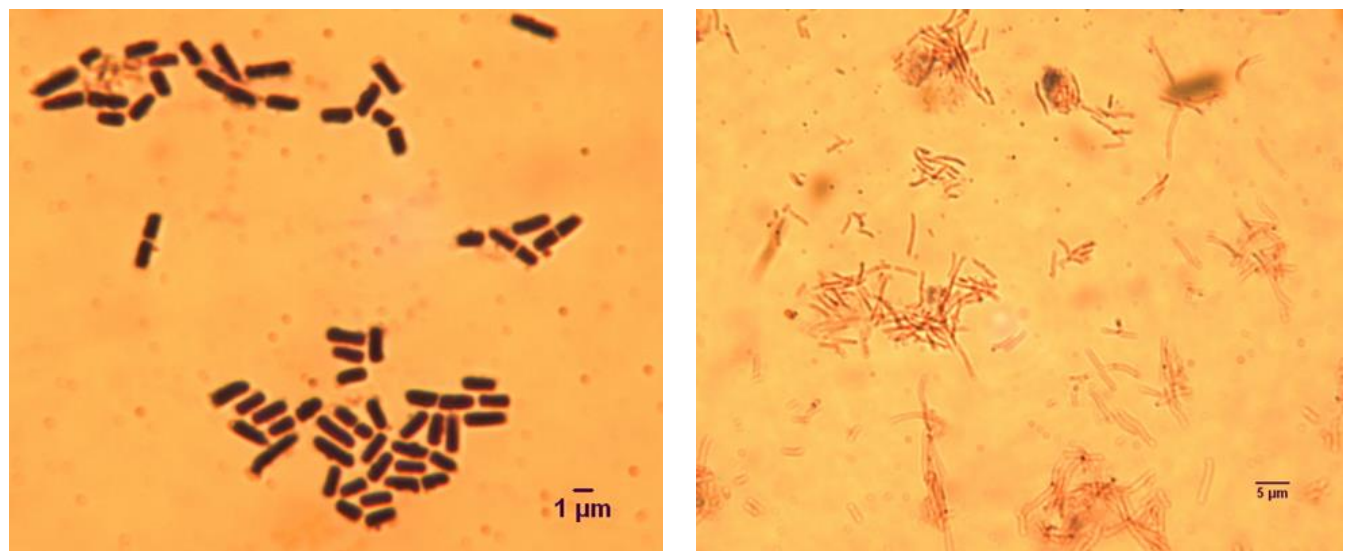

Figure 6 Gram staining of bacterial isolate showing rod-shaped and filamentous bacteria

\section{Conclusions}

Revegetation of oil sands tailings in the post-mined landscape is no doubt challenging. Historically, reclamation focused on the establishment of upland forest vegetation and the use of soil materials (peat and overburden) followed by repeated fertiliser application to improve plant growth. Plants used have 
been mainly Barley (Hordeum vulgare) to provide vegetation cover and erosion control followed by trees and shrubs in subsequent years (BGC Engineering Inc., 2010).

This study covers the second year of growth on tailings sand without a soil cover at Pond 5 . Results to-date are encouraging, showing that native plants can grow in direct tailings sand with little input such as fertiliser and organic amendments. Despite a dry spell in the early part of the growing season, all plants performed well, going into seed set by the end of the growing season. Rainfall after June $15^{\text {th }}$ replenished ground moisture for the plants. The greatest benefit from any organic amendment is to improve soil physical characteristics. Alfalfa pellets seemed to have provided moisture retention, thereby facilitating germination and providing the plants a good basis for establishment. In 2010, we saw that an alfalfa pellet rate of $5 \mathrm{t} / \mathrm{ha}$ and fertiliser rate of $50 \mathrm{~kg} \mathrm{~N} /$ ha provided the best option for facilitating establishment and growth of native species, oats and barley on tailing sands. In 2011, no alfalfa pellet and fertiliser application occurred. Treatments applied in 2010 had no bearing on plant heights. June grass and the native mix had significantly higher percent cover than fringed brome grass. This was expected as the fringe brome grass had low emergence in 2010. Higher level application rates of both alfalfa pellets and fertiliser had no influence on percent cover by plants. A fertiliser rate of $250 \mathrm{~kg} \mathrm{~N}$ broadcasted when the plants were at the seedling stage resulted in tissue injury and many plants did not recover. As a result, these plots had less cover and confounded the benefit of the higher alfalfa pellets rate.

The low nutrient status of the tailings sand can be overcome by adding fertiliser. In 2011, available nitrogen in the soil decreased to below detectable levels, although plant tissue analysis ranged from 1-2\%. Nitrogen in aboveground tissues of native species (Knops et al., 2002) is approximately 3-4\%. It is assumed most of the applied nitrogen was lost either through soil leaching or volatilisation.

Native species are better adapted to low levels of nutrients. Tilman (1986) demonstrated a highly significant tendency for early successional species to grow more rapidly at low nitrogen levels and to acquire more nitrogen per plant from nitrogen-poor soils than late successional species. Additionally, late successional species did not grow more rapidly at high nitrogen levels than early successional species. Nitrogen pools in the soil at the end of the 2012 growing season were low because of uptake by plants and microbes and leaching. This uptake varies within the species used in this project. Wedin and Pastor (1993), Wedin (1990) and Jackson and Caldwell (1992) found choice of species and vegetation layers to influence the nitrogen pool available to plants. Atmospheric deposition of $\mathrm{N}$ and microbial association with the plant exudates definitely are playing a role.

The importance of soil microbes in supporting plant community development has always been an area of interest in reclamation (Visser et al., 1984; Greer et al., 2007; Onwuchekwa, 2012). We investigated if there was any association of microbes with these native species. Woosaree and Yang (2012) found four genera (Arthrobacter, Bacillus, Flavobacterium and Pseudomonas), that contain either plant growth promoting or hydrocarbon degrading species to be associated with the roots of these grasses. Root exudates and root turnover are important sources of carbon for soil microbes (Grayston et al., 2001) which is contributing to $\mathrm{N}$ uptake by these grasses. The use of native species provides the best option for temporary reclamation because of their ability to compete for soil nitrogen in a nutrient poor environment. Ecosystem response to fertilisation is variable and can be controversial as it often leads to aggressive growth of undesirable species and an unwanted species composition.

Sand movement as a result of strong wind can impact emergence and growth on Pond 5. This study showed that these species can provide long-term protection against wind erosion. Tall species such as slender wheatgrass and Fringe brome grass tolerate a higher amount of sand burial. Low stature species such as June grass and spike trisetum also seem not to be affected by the blown in sands. The sand mound serves as niche habitat for colonising species as observed in this study.

These plants with their deep roots do not seem to be constrained by the coke layer. All of them showed good tolerance to withstand sand burial and contribute to stabilisation of the tailings sand.

What is striking with this study is that these native species are thriving and naturally occurring microorganisms are found to be associated with plant growth. Whether growth of these plants is 
sustainable without further supplement of fertiliser remains to be seen. Continued monitoring is essential to ensure sustainability for the duration of the cover crop program and species that performed well will be valuable for incorporation in reclamation seed mixtures in future projects in the oil sands to ensure a successful and sustainable plant community.

\section{Acknowledgement}

Suncor Energy provided funding for this study and Western Alfalfa Milling Company Ltd, Norquay, Saskatchewan donated the alfalfa pellets. We thank Melinda Mamer, planning manager and her team, Bill Tully, operations manager and his team and Francis Salifu (formerly of Suncor Energy), for support in executing this project. The assistance of Kristine Dahl and Christine Daly for coordinating this project is appreciated. Our thanks also go to Marshall McKenzie and Tania McDonald for their technical expertise, to Ruth Eckford for nutrient analysis, Jian Yang for microbial identification and to Michelle Hiltz for statistical analysis.

\section{References}

BGC Engineering Inc (2010) Review of reclamation options for oil sands tailings substrates, Oil Sands Research and Information Network, University of Alberta, School of Energy and the Environment, Edmonton, Alberta, OSRIN Report No. TR-2, 59 p.

Campbell, C.R. and Plank, C.O. (1998) Preparation of plant tissue for laboratory analysis, Reference Methods for Plant Analysis, Y. Yash and P. Kalra (eds), Soil and Plant Analysis Council, Boca Raton: CRC Press, 1998, pp. 39-41.

Chapman, K.J. and Das, S.B. (2010) Survey of Albertans' value drivers regarding oil sands development and reclamation, Oil Sands Research and Information Network, University of Alberta, School of Energy and the Environment, Edmonton, Alberta, OSRIN Report No. TR-3, 13 p.

Grayston, S.J., Griffith, G.S., Mawdsley, J.L., Campbell, C.D. and Bardgett, R.D. (2001) Accounting for variability in soil microbial communities of temperate upland grassland ecosystems, Soil Biology \& Biochemistry, Vol. 33, pp. 533-551.

Greer, C., Lefrançois, E., Quoreshi, A., Khasa, D., Fung, M., Whyte, L. and Roy, S. (2007) Alder-Frankia symbionts enhance the remediation and revegetation of oil sands tailings, viewed 16 May 2012. http://www.esaa-events.com/remtech/2007/pdf/07-Greer.pdf.

Horneck, D.A. and Miller, R.O. (1998) Determination of total nitrogen in plant tissue, Reference Methods for Plant Analysis, Y. Yash and P. Kalra (eds), Soil and Plant Analysis Council, Boca Raton: CRC Press, 1998, pp. 81-83.

Jackson, R.B. and M. Caldwell (1992) Shading and the capture of localized soil nutrients: nutrient contents, carbohydrates, and root uptake kinetics of a perennial tussock grass, Oecologia 91, pp. 457-462.

Knops, J, Bradley, K. and Wedin, D. (2002) Mechanisms of plant species impacts on ecosystem nitrogen cycling, Ecology Letters, Vol. 5(3), pp. 454-466.

Maynard, D.G., Kalra, Y.P. and Crumbaugh, J.A. (2008) Nitrate and exchangeable ammonium nitrogen, C.R. Martin and R. Carter (eds), Canadian Society of Soil Science, Boca Raton: Lewis Publisher, pp. 98-105.

Onwuchekwa, N.E. (2012) Enhanced revegetation and reclamation of oil sand disturbed land using mycorrhizae, M.Sc. Thesis, Department of Renewable Resources, University of Alberta, Edmonton, Alberta, $102 \mathrm{p}$.

Paskey, J. and Steward, G. (2012) The Alberta oil sands, journalists, and their sources, Oil Sands Research and Information Network, School of Energy and the Environment, University of Alberta, Edmonton, OSRIN Report No. TR-17, 33 p.

Salifu, K.F., Woosaree, J., Wells S. and Anderson, J.B. (2011) Innovative techniques to improve reclamation practices in Alberta oil sands, in Proceedings Sixth International Conference on Mine Closure (Mine Closure 2011), A.B. Fourie, M. Tibbett and A. Beersing (eds), 19-21 September 2011, Lake Louise, Canada, Australian Centre for Geomechanics, Perth, Vol. 1, pp. 191-198.

SAS Institute Inc. (2010) SAS Release 9.3 (64-bit) for Windows 7, SAS Institute Inc., Cary, N.C.

Tilman, D. (1986) Nitrogen-limited growth in plants from different successional stages, Ecology, Vol. 67(2), pp. 555-563.

Visser, S., Griffiths, C., Parkinson, D. (1984) Reinstatement of biological activity in severely disturbed soils - effects of mining on the microbiology of three minespoils and the microbial development in the minespoils after amendation and planting. Alberta Land Conservation and Reclamation Council, Report RRTAC 84-4, Volume I, 283 p.

Wedin, D.A. (1990) Nitrogen cycling and competition among grass species, Department of Ecology, Evolution and Behavior, University of Minnesota, St. Paul, MN, 92 p.

Wedin, D.A. and Pastor, J. (1993) Nitrogen mineralization dynamics in grass monocultures, Oecologia, Vol. 96, pp. $186-192$.

Woosaree, J. and Hiltz, M. (2010) Cover crop program for tailings sand stabilization, prepared for Suncor Energy. Alberta Innovates Technology Futures, Vegreville, Alberta, $25 \mathrm{p}$.

Woosaree, J. and Yang, J. (2012) Assessment of microbial growth from pond 5 cover crop research, Prepared for Suncor Energy. Alberta Innovates Technology Futures, Vegreville, Alberta, $10 \mathrm{p}$. 